\title{
Aerial surveillance to detect kauri dieback in New Zealand
}

\author{
A. Jamieson ${ }^{1,2}$, I.E. Bassett ${ }^{1}$, L.M.W. Hill ${ }^{1}$, S. Hill ${ }^{1}$, A. Davis ${ }^{1}$, N.W. Waipara ${ }^{1}$, \\ E.G. Hough ${ }^{3}$ and I.J. Horner ${ }^{3}$ \\ ${ }^{1}$ Auckland Council, Private Bag 92300, Auckland 1142, New Zealand \\ ${ }^{2}$ Wild Earth Media Ltd, P.O. Box 4, Oneroa, Waiheke Island 1840, New Zealand \\ ${ }^{3}$ The New Zealand Institute for Plant \& Food Research Limited, Hawke's Bay, \\ Private Bag 1401, Havelock North, New Zealand \\ Corresponding author: nick.waipara@aucklandcouncil.govt.nz
}

\begin{abstract}
The causal agent of kauri dieback, Phytophthora 'taxon Agathis' (PTA), poses a significant threat to kauri (Agathis australis) in northern New Zealand. Ground-based field surveys have previously confirmed PTA presence at several locations across Auckland and Northland. However, ground surveys are limited to areas adjacent to tracks because of difficulty and cost associated with off-track access in steep terrain, along with concern about furthering spread of PTA. A methodology for aerial photographic surveillance of kauri dieback was developed and implemented in Waitākere Ranges, Hunua Ranges and adjacent forest areas. Using recently developed GPS technology, photographs were embedded with position data so unhealthy trees were easily located later for ground-truthing. Aerial survey was found to be a time- and cost-effective method for surveying large, inaccessible areas of forest for kauri dieback. The methodology would also be applicable for detection of visible disease or damage symptoms in other canopy tree species.
\end{abstract}

Keywords kauri, Agathis australis, Phytophthora, biosecurity, photography, GPS, geotagging.

\section{INTRODUCTION}

Kauri (Agathis australis, Araucariaceae) is an endemic conifer naturally distributed extensively in New Zealand north of $38^{\circ} 07^{\prime}$ S. Kauri trees are ecosystem engineers, producing deep banks of leaf litter resulting in very acid soils and consequently exerting a profound influence on surrounding vegetation communities (Wyse 2012; Wyse et al. 2013). Kauri are also of great cultural significance, as a taonga (treasure) species for Māori, a significant icon for New Zealanders of all ethnicities, and a major tourist attraction for northern New Zealand. Kauri forests experienced substantial range contractions as a result of historical logging and fires (Ecroyd 1982), but the key threat and management issue for remaining kauri populations is kauri dieback.

Kauri dieback is caused by the Oomycete, or water mould, Phytophthora 'taxon Agathis' (PTA), which is presumed to be non-native to New Zealand (Beever et al. 2009). Symptoms of kauri dieback include root and collar rot, resinexuding lesions, severe chlorosis, defoliation/ canopy thinning, and tree mortality (Beever et al. 2009; Waipara et al. 2013). Kauri dieback was first recorded from Great Barrier Island (Gadgil 1974), but was not reported from the mainland 
until 2006, although it had likely been present for many years prior to detection. Since then, kauri dieback has been confirmed from numerous kauri stands in Auckland and Northland and more recently also from Coromandel.

In 2008 PTA was declared an Unwanted Organism under the Biosecurity Act, and is subject to a joint agency management programme comprising Māori, Department of Conservation, Ministry for Primary Industries and Regional Councils. Surveillance and monitoring to determine disease distribution and spread are key aspects of kauri dieback management. A passive surveillance programme utilises public reports of diseased trees, which can be followed up by ground truthing including soil and/or tissue sampling to confirm disease presence (Waipara et al. 2013). Ground survey methods can also be targeted to other high risk sites such as park entrances and along track networks. However, ground surveys are inappropriate for extensive off-track surveillance due to several limitations, including the length of time required to cover large areas, inaccessibility of steep terrain, and the potential to further spread the soil-borne pathogen. Existing remote sensing technology has been successfully used for detection and mapping of forest canopy damage due to attack by insect herbivores (e.g. Wulder et al. 2009) or pathogens including other Phytophthora taxa (e.g. Fletcher et al. 2001; Martins et al. 2007). However, preexisting technology is not sufficiently sensitive to detect kauri dieback. Furthermore, cost was an important consideration in the development of these methods; the technology described here represents a much lower cost option than available alternatives. This paper describes the development and implementation of aerial photographic surveillance methodology to guide and complement ground surveillance methods for kauri dieback.

\section{MATERIALS AND METHODS Flight planning for site prioritisation}

Aerial grid searches covering the entire Waitākere and Hunua Ranges were considered to be prohibitively costly and inefficient. Instead, flight plans were developed prioritising areas where kauri trees were known to be concentrated based on previous aerial photographs and institutional knowledge. A range of different aged stands of trees were included. The flight plans incorporated the following variables: flight safety and refuelling considerations; efficient flight path to minimise cost; thorough coverage of priority areas known to contain substantial kauri stands; adequate coverage of areas where kauri presence was uncertain. The planned flight path was adjusted in-flight as required in response to terrain, visibility and observed kauri distributions.

\section{In-flight methods}

Surveys were undertaken in a Robinson R44 Raven II helicopter, chosen for its combination of power, manoeuvrability and cost. Helicopters are more suitable than fixed wing aircraft for this kind of survey work due to advantages such as ease of manoeuvrability, ability to descend low to trees to confirm identification if required, and because sight lines from GPS satellites are not obstructed by the wing or fuselage. With a relatively low fuel burn rate this helicopter is also a more sustainable option than larger, more powerful machines. Flights were undertaken during the middle part of the day to take advantage of a relatively high sun angle. Each flight included a photographer and one additional observer.

All kauri trees (or groups of trees) that appeared unhealthy were photographed. In addition, healthy kauri trees were also photographed to provide a baseline for future monitoring of their health. Photography of healthy trees was conducted most thoroughly in priority areas and less comprehensively in lower priority areas. Digital photographs were shot with recent model Nikon DSLR cameras and large aperture zoom lenses, chosen for their high resolution and speed of operation. This generated a set of photographs of much higher resolution than existing vertical aerial technology, with the additional advantage of an oblique camera angle that allowed unhealthy canopy to be more readily differentiated from understory vegetation. A di-GPS brand receiver attachment was used to geotag every photograph (i.e. automatically capture and embed GPS 
latitude/longitude position coordinates). The actual location of unhealthy or dead kauri trees was captured by positioning the helicopter directly above them to allow vertical photographs to be taken. In addition, a Garmin GPSMAP 296 aviation GPS unit was used to record detailed flight paths.

\section{Ground truthing}

Follow-up ground surveys were conducted in areas identified by aerial survey as possible sites of PTA infection. Kauri trees were randomly sampled within potentially diseased areas to delimit the infection. Trees were categorised by appearance as asymptomatic, possibly infected, or highly symptomatic of kauri dieback infection. Soil sampling was conducted near the tree(s) considered most likely to be infected at each site. Soil samples (ca $200 \mathrm{~g}$ each) were taken from four positions around the base of the target tree, always including the side of the tree with the most active bleed. Samples were taken from the soil surface to a depth of $20 \mathrm{~cm}$. Most samples were taken at $60 \mathrm{~cm}$ distance from the tree, but in some cases this was extended up to $150 \mathrm{~cm}$ where roots made nearer sampling impossible. Soil samples were then screened for PTA presence by Plant \& Food Research using a previously described extended soil baiting method (Beever et al. 2010).

\section{RESULTS}

\section{Outcome of aerial surveys}

Nearly 17,000 ha of the Waitākere Ranges were surveyed (approximately 825 linear km flown) during approximately $12 \mathrm{~h}$ of flight time spread across 3 days in autumn and early winter of 2010 . In total 2091 photographs of kauri were taken, including 835 images of kauri trees showing clear signs of ill health. Most images included multiple trees and most sites were recorded in several photographs. Therefore the number of images reported here does not reflect the absolute number of symptomatic trees observed. Over 20 new key locations of canopy ill health in the Waitākere Ranges were identified by aerial survey, having been undetected by previous ground surveying.
Approximately 20,000 ha of the Hunua Ranges were surveyed, with approximately 1500 linear $\mathrm{km}$ flown within the survey area. Conducted over 6 days in autumn and winter of 2011, the survey totalled approximately $17 \mathrm{~h}$ of flight time. In total, the Hunua survey yielded 2941 aerial photographs, including 293 images of kauri showing poor canopy health, although as for the Waitākere survey, this number reflects considerable duplication of images.

\section{Data mapping}

Geotagged photo locations were compiled into an interactive digital map in the Auckland Council GIS Viewer. Each photo location point is linked to the corresponding image at screen resolution, and full resolution digital photographs are archived on Auckland Council's server.

\section{Ground truthing}

Ground truthing in the Waitākere Ranges surveyed 1706 kauri trees, 634 of which were classed as symptomatic of kauri dieback, and a further 339 were categorised as possibly infected with PTA. Of the 59 soil samples taken, 26 tested positive for PTA. ESRI ArcGIS mapping software was then used to map and analyse these survey points, resulting in the creation of zones representing varying likelihood of kauri dieback infection ranging from possible infection to infection confirmed by identification of PTA in culture. The combination of aerial survey and ground truthing indicates that of the 2719 ha of dense kauri forest within the Waitākere Ranges, around $7.9 \%$ is already infected with PTA, and a further $2.7 \%$ is possibly infected (Figure 1).

Fifty-three sites in and around the Hunua Ranges received ground visits to follow up on poor canopy health identified in the aerial survey. Only twelve of these sites contained trees exhibiting symptoms sufficiently consistent with PTA to warrant soil sampling. PTA was not detected in any of the soil samples taken from Hunua, and to date the Hunua region is still thought to be unaffected by kauri dieback. Ground inspection indicated that poor canopy health detected in aerial surveying was most commonly attributable to one or more of the following factors: environmental 


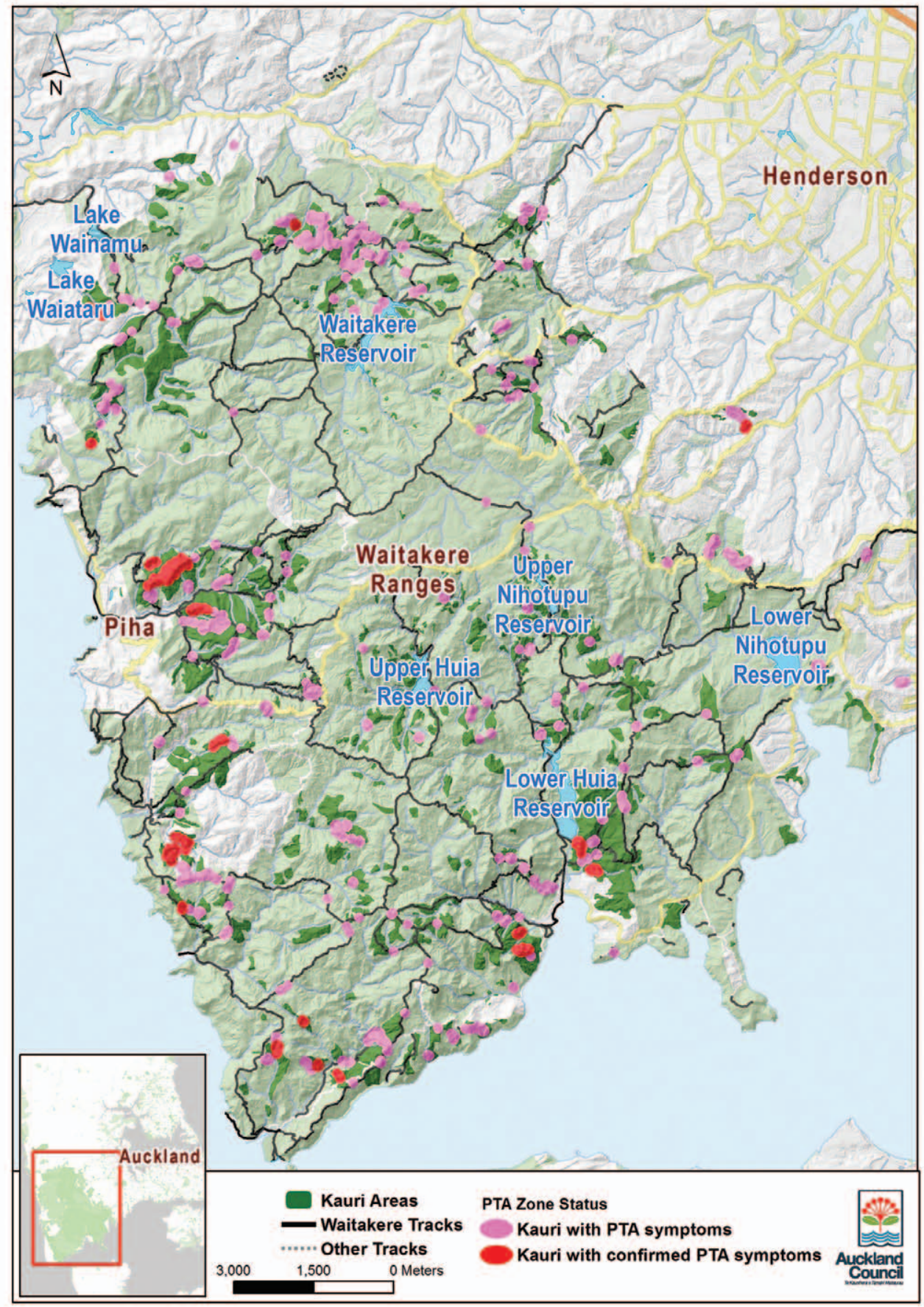

Figure 1 Distribution of possible and confirmed kauri dieback infection in the Waitākere Ranges, Auckland. 'Possible' kauri dieback sites are those for which canopy thinning was observed during aerial surveillance, but which have not to date been confirmed by ground-truthing. 'Confirmed' kauri dieback infections have tested positive for PTA in soil and/or tissue sampling. N.B. for visual clarity in this map, individual data points are not to scale. 
stresses (e.g. poor, dry soils), natural decline due to age, presence of other Phytophthora pathogens (most often $P$. cinnamomi) or environmental damage (e.g. lightning strike or damage from neighbouring tree falls).

\section{DISCUSSION}

Aerial survey allows the rapid observation of large tracts of forest that would take months to survey on foot, and overcomes access issues associated with steep terrain. Consequently aerial survey identified numerous previously undetected sites of unhealthy kauri canopy at widely scattered locations across public and private land. In addition, aerial survey increased the known extent of unhealthy trees at some sites where PTA had previously been identified.

Geotagging accurate location data directly with aerial photographs enabled subsequent ground survey efforts to be targeted to priority areas, thereby maximising the efficiency of ground surveying. The cost of aerial surveillance could be reduced by photographing only symptomatic trees rather than extending photography to healthy areas as was done in this survey. However, capture of images and locations of healthy trees will provide a valuable tool for future monitoring of canopy health.

Aerial surveillance does have some limitations for disease detection. Aerial canopy survey is unable to confirm that unhealthy trees are indeed infected with PTA, as other factors such as drought may also contribute to ill health. Therefore aerial surveying is not a stand-alone diagnostic tool, but rather complements and enhances the efficiency of ground-based surveys. Furthermore, kauri infected with PTA only exhibit substantial canopy dieback in the later stages of the disease, considerably after other symptoms such as gum bleeding (Waipara et al. 2013). Therefore aerial surveying is only able to detect kauri dieback sites when the disease is already in an advanced stage, and is less useful for early disease detection.

Despite these limitations, aerial surveillance using digital photography and geotagging technology has been shown to be a highly costand time-effective tool in the detection of kauri dieback. To date, ground based inspections have observed that PTA is widespread with multiple disease foci in both Northland and Auckland (Beever et al. 2009; Beauchamp 2013; Waipara et al. 2013) and more recently PTA has also been detected in Coromandel. The aerial methodology reported here should therefore be repeated systematically across all remaining kauri areas to complete surveillance for kauri dieback in forests where no or minimal field inspections have been undertaken to date. Detailed aerial survey using the methods described here has recently been completed for Waiheke, Pōnui, Kawau and Hauturu (Little Barrier) Islands in the Hauraki Gulf. Sites with poor canopy health or dead kauri in these locations are yet to be checked with follow-up ground survey. Additionally, the same methodology could be used in the detection of canopy disease or damage in other forest tree species.

\section{ACKNOWLEDGEMENTS}

Dr Tony Beauchamp (Department of Conservation), Jack Craw, Scott McKusker, Adrian Rose and Willow van Huegten (Auckland Council) are all thanked for their contributions to this paper.

\section{REFERENCES}

Beauchamp AJ 2013. Surveillance 2 sample and site detection probabilities. Department of Conservation, Northland Conservancy Report DOCDM-1188756. Department of Conservation, Wellington, New Zealand. 15 p.

Beever RE, Waipara NW, Ramsfield TD, Dick MA, Horner IJ 2009. Kauri (Agathis australis) under threat from Phytophthora? In: Phytophthoras in Forests and Natural Ecosystems. Proceedings of the fourth meeting of the International Union of Forest Research Organisations (IUFRO) working party. 26-31 August 2007. Monterey, California, USA. Pp. 74-85.

Beever RE, Bellgard SE, Dick MA, Horner IJ, Ramsfield TD 2010. Detection of Phytophthora taxon Agathis (PTA). Landcare Research Contract Report LC0910/137, Landcare Research, Auckland, New Zealand. 78 p. 
Ecroyd CE 1982. Biological flora of New Zealand 8. Agathis australis (D. Don) Lindl. (Araucariaceae), Kauri. New Zealand Journal of Botany 20: 17-36.

Fletcher RS, Skaria M, Escobar DE, Everitt JH 2001. Field spectra and airborne digital imagery for detecting Phytophthora foot rot infections in citrus trees. HortScience 36: 94-97.

Gadgil PD 1974. Phytothphora heveae, a pathogen of kauri. New Zealand Journal of Forestry Science 4: 59-63.

Martins L, Castro J, Macedo W, Marques C, Abreu C 2007. Assessment of the spread of Chestnut ink disease using remote sensing and geostatistical methods. European Journal of Plant Pathology 119: 159-164.

Waipara NW, Hill S, Hill LMW, Hough EG, Horner IJ 2013. Surveillance methods to determine tree health, distribution of kauri dieback disease and associated pathogens. New Zealand Plant Protection 66: 235-241.
Wulder MA, White JC, Grills D, Nelson T, Coops NC, Ebata T 2009. Aerial overview survey of the mountain pine beetle epidemic in British Columbia: Communication of impacts. BC Journal of Ecosystems and Management 10: 45-58.

Wyse S 2012. Growth responses of five forest plant species to the soils formed beneath New Zealand Kauri (Agathis australis). New Zealand Journal of Botany 50: 411-421.

Wyse SV, Burns BR, Wright SD 2013. Distinctive vegetation communities are associated with the long-lived conifer Agathis australis (New Zealand Kauri, Araucariaceae) in New Zealand rainforests. Austral Ecology DOI: 10.1111/aec.12089. 